Review

\title{
Monoliths in Bioprocess Technology
}

\section{Vignesh Rajamanickam ${ }^{1,2}$, Christoph Herwig ${ }^{1,2}$ and Oliver Spadiut ${ }^{1,2, *}$}

1 Research Division Biochemical Engineering, Institute of Chemical Engineering, Vienna University of Technology, Gumpendorfer Strasse 1A/166-4, 1060 Vienna, Austria;

E-Mails: vignesh.rajamanickam@tuwien.ac.at (V.R.); christoph.herwig@tuwien.ac.at (C.H.)

2 Christian Doppler Laboratory for Mechanistic and Physiological Methods for Improved Bioprocesses, Institute of Chemical Engineering, Vienna University of Technology, Getreidemarkt 9/166, A-1060 Vienna, Austria

* Author to whom correspondence should be addressed; E-Mail: oliver.spadiut@tuwien.ac.at; Tel.: +43-(0)1-58801-166473; Fax: +43-(0)1-58801-166980.

Academic Editor: Zuzana Zajickov

Received: 6 February 2015 / Accepted: 14 April 2015 /Published: 17 April 2015

\begin{abstract}
Monolithic columns are a special type of chromatography column, which can be used for the purification of different biomolecules. They have become popular due to their high mass transfer properties and short purification times. Several articles have already discussed monolith manufacturing, as well as monolith characteristics. In contrast, this review focuses on the applied aspect of monoliths and discusses the most relevant biomolecules that can be successfully purified by them. We describe success stories for viruses, nucleic acids and proteins and compare them to conventional purification methods. Furthermore, the advantages of monolithic columns over particle-based resins, as well as the limitations of monoliths are discussed. With a compilation of commercially available monolithic columns, this review aims at serving as a 'yellow pages' for bioprocess engineers who face the challenge of purifying a certain biomolecule using monoliths.
\end{abstract}

Keywords: monolith; pDNA purification; virus purification; protein purification; commercially available monolith 


\section{Introduction}

The Centre for Chemical Process Safety (CCPS) defines a bioprocess as a process that makes use of microorganisms, cell culture or enzymes to manufacture a product or to complete a chemical transformation [1]. In other words, a bioprocess envelops production and purification of a biomolecule that can be of therapeutic (e.g., protein-based therapeutic drugs) or economic importance (e.g., food industry, waste water treatment). As shown in Figure 1, a typical bioprocess is comprised of upstream (strain engineering, production of target biomolecule) and downstream processes (clarification, separation, purification). In a typical downstream process, the product undergoes capture, purification and/or polishing steps to yield the final, purified preparation. Of course, these steps and their execution depend on the purity of the starting material; e.g., the purification of an intracellular biomolecule from $E$. coli might require more purification steps than the purification of a secreted product from yeast. During the last decade, production titers in the upstream dramatically increased due to strain engineering, media optimization and bioprocess engineering approaches. However, the downstream process did not develop at the same pace, which is why product purification actually describes the bottleneck of a typical bioprocess. To date, conventional downstream methods, like centrifugation and filtration, are not able to handle the high product titers coming from the upstream process [2], which is why alternative, fast and efficient separation techniques are needed. Chromatography with particle-based resins has become the backbone of downstream processing for biomolecules, such as viruses, nucleic acids and proteins. However, mass transfer in particle-based resins occurs through diffusion, which is why purification of large biomolecules, such as glyco-proteins and immunoglobulins, takes a long time. This can be critical for unstable products, which is why faster purification methods are needed. In the past twenty years, monolithic columns have become popular as an efficient tool for the purification of large biomolecules due to their high mass transfer properties and short purification times [3]. Monoliths are a special type of chromatographic column having a single block of a homogenous stationary phase with many interconnected channels [4]. The stationary phase of the monolith can be of various chemistries, allowing the purification of different kinds of biomolecules with different characteristics. Monoliths are the fourth generation chromatography material [3], succeeding beads, porous particle-based columns and membrane adsorbers. In the last two decades, numerous articles describing preparation, properties and applications of monolithic columns were published [4-18]. In contrast, this review focuses on the applied aspect of monoliths and describes recent applications of monoliths for the purification of biomolecules. Thus, this review serves as a 'yellow pages' for bioprocess engineers who want to purify a certain biomolecule by monoliths.

\section{Advantages and Limitations of Monoliths}

The complexity of any purification process is finding the optimal balance between surface area, porosity, pore size and distribution and other physical and chemical properties of the chromatographic support, such as mass transfer properties and flow distribution. In this respect, monoliths show several advantages over particle-based resins. 


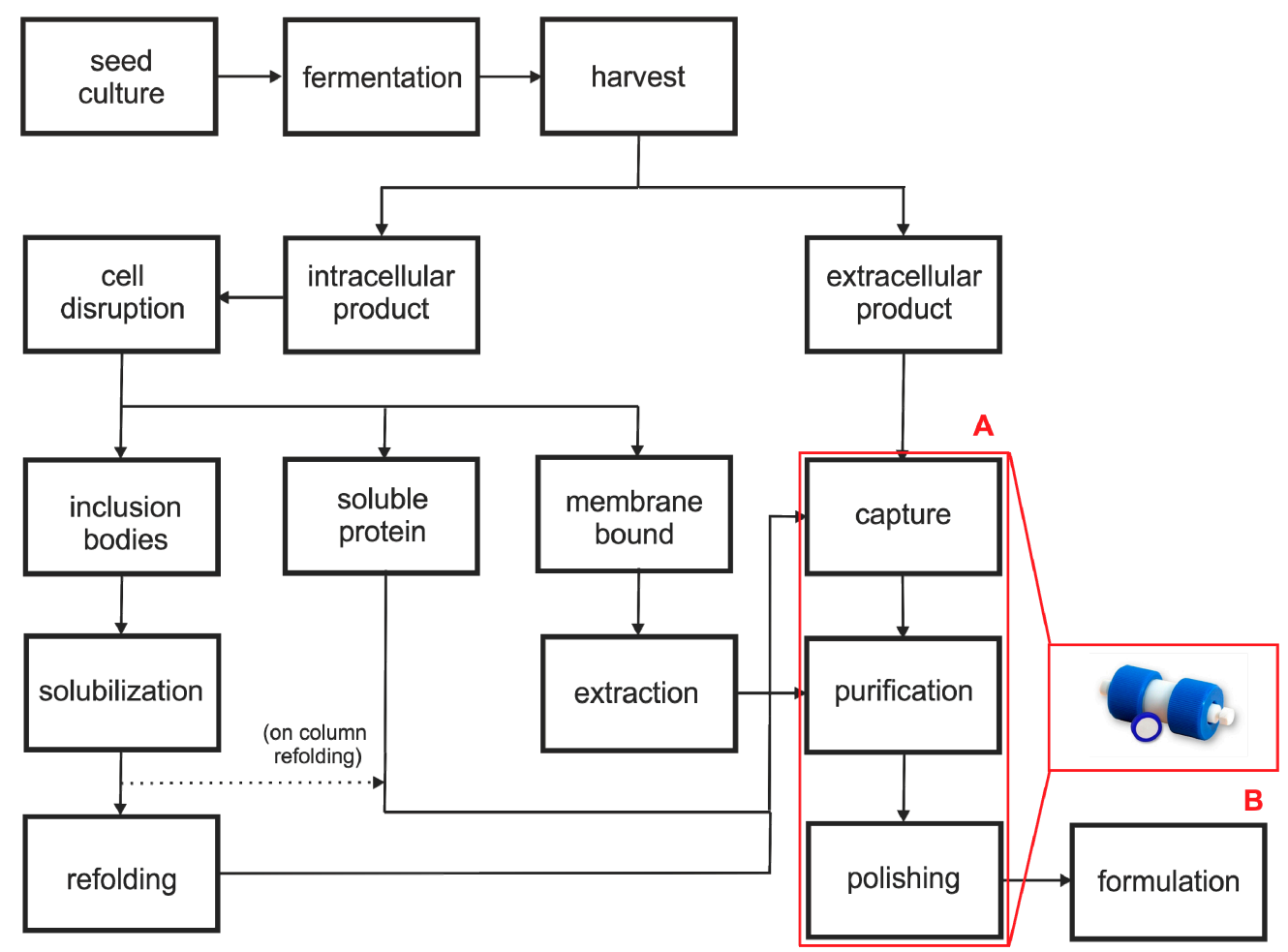

Figure 1. Schematic diagram of a typical bioprocess. (A) different downstream unit operations, $(\mathbf{B})$ convective interaction media $\left(\mathrm{CIM}^{\circledR}\right)$ monolithic column [19].

\subsection{Advantages of Monolithic Columns}

\subsubsection{Convective Flow}

In particle-based resins, separation processes happen by diffusion into pores. The longitudinal diffusion of the target analyte declines with increasing flow rate. Furthermore, the diffusion coefficient, which is comprised of both diffusive and convective components, is predominantly dependent on convection for higher flow velocities, which, in turn, is dependent on the pore size [20]. In contrast to particle-based resins, in monoliths, the separation of biomolecules dominantly happens by convective flow through channels having a diameter of more than $1,000 \mathrm{~nm}$. This allows high flow velocity and, therefore, high throughput purifications [16].

\subsubsection{Porosity}

Monolithic columns have high porosity due to their large interconnected channels. Optimization of pore size and pore distribution can be done over a wide range by changing the porogen composition, porogen to monomer ratio and polymerization temperature [21-25]. Owing to their high bed porosity, the pressure drop in monoliths is much lower in comparison to particle-based resins.

\subsubsection{Adsorption Area and Dynamic Binding Capacity}

Monolithic columns have a low absolute surface area, but a high adsorption area due to their porous structure [3], allowing a high dynamic binding capacity (DBC). Another main advantage of monoliths is their flow-independent DBC allowing straight-forward scalability [3,26-28]. A direct comparison 
between monoliths and particle-based resins for the purification of virus-like particles from yeast homogenate has been conducted by Burden et al. The authors concluded that the monoliths are three-fold superior in terms of DBC with equivalent recovery in yield (90\%) compared to particle-based resins [29].

\subsubsection{Separation Time}

Due to the high flow velocity and low pressure drop, the overall process time using monoliths is much lower compared to particle-based resins [30]. For example, Rupar et al. were able to purify potato virus $\mathrm{Y}$ with the help of monolithic columns in half the separation time in comparison to classical methods. Even though the yield achieved by monolithic columns was slightly lower than by classical methods, the possibility for easy scale-up offered valuable compensation for subsequent industrial-scale purification [31]. In another study, a direct performance comparison between conventional and monolithic C-18 columns was conducted, and it was shown that separation time was decreased five-fold by using monolithic columns [32].

\subsubsection{Stationary Phase}

Monoliths allow a high degree of freedom for the operator, since they can be manufactured from various raw materials (such as polymethacrylate, polyacrylamide, polystyrene, silica and cryogels) with different morphologies and channel diameters [33]. In general, the monolithic media can be classified into two categories, namely organic, polymer-based and inorganic, silica-based media. The main advantages of organic, polymer-based media are $\mathrm{pH}$ stability and customizability, but the columns are mechanically not very stable, which shortens the column life-time. On the other hand, inorganic, silica-based monoliths show excellent stability and separation efficiency. However, manufacturing is sophisticated and time consuming [34]. Recently, also organic-inorganic hybrid monoliths have been prepared combining the advantages of both [34-36].

\subsubsection{Customizability}

Monoliths can be customized to the needs of the user, since there are various stationary phase chemistries, active binding sites and shapes and sizes (disks, tubes) available. Although the shape of the monolith per se does not present a significant advantage, a minor advantage to be noted is that monolithic disks $(0.34 \mathrm{~mL})$ do not have a specific flow direction, enabling back-flush to encounter clogging problems. BIA separations, Slovenia, offers small 0.34-mL monolithic disk columns comprising a wide variety of stationary phases [19]. Since monolithic columns do not lose resolution with scale-up, preliminary, less expensive characterization and screening studies using analytical-scale disks are possible.

\subsubsection{Scalability}

Monolithic supports are easy to scale up without the need for column modifications [3,26]. Monolithic disks can be stacked up to four disks in the same housing, increasing efficiency and capacity without compromising resolution [3]. Monoliths have overcome the mass transfer problems posed by particle-based columns, and commercial monolithic columns up to $8 \mathrm{~L}$ are available [3]. 


\subsection{Limitations of Monolithic Columns}

Mass transfer in monoliths is based on convection and, hence, cannot be used for size exclusion chromatography (SEC), since SEC is based on the difference in diffusivity of individual molecules into pores. Recently, it was shown that biomolecules can still be separated by size by using friction in the monolithic support, called slalom chromatography [37-39]. However, monolithic columns for slalom chromatography have to be further optimized and have not been utilized in industry yet [3].

Fouling and clogging is another major limitation in most chromatographic columns, as it results in the reduction of DBC and an increase in the pressure drop across the column, which decreases the life span of the column significantly. As mentioned before, back-flush is possible only in smaller monolithic disks (with axial flow) to reverse fouling and clogging and is not possible in tubular monolithic columns (with radial flow).

Lipids are a major class of biological foulants, as they bind irreversibly and are hard to remove from the column. Burden et al. tackled lipid fouling by sample pretreatment, using Amberlite/XAD-4 beads for lipid removal, which doubled the dynamic binding capacity of a monolithic disk column [29].

\section{Applications of Monoliths}

Monolithic supports have been extensively used for the purification of different biomolecules. Boehringer Ingelheim (Austria) established the first industrial process for pDNA purification using monolithic supports [16]. Here, we want to sum up recent studies describing monolithic purifications of the three major biomolecule classes: (1) viruses; (2) nucleic acids; and (3) proteins. We describe one success story for each biomolecule in more detail and compare it with conventional downstream strategies. We want to present the review as a yellow pages for bioprocess engineers, who face the challenge of purifying either of these biomolecules.

\subsection{Virus Purification}

Viruses can be used for the production of recombinant proteins and for gene therapy applications [40,41] and describe a major class of biomolecules in industry. Today, conventional virus purification includes centrifugation, filtration and chromatography, which either returns low yields (e.g., only $1 \%$ for ultracentrifugation [42]) or is time consuming and tedious. For several years, ion exchange monolithic supports have been extensively used for the purification of viruses. In 2013, Rupar et al. purified the potato virus Y (PVY) by conventional methods and by monoliths and compared both strategies (Figure 2; [31]). The authors used a CIM $^{\circledR}$ QA (quaternary amine) monolith column and achieved product recovery and purity comparable to conventional purification methods involving ultracentrifugation. However, they could reduce the overall process time by more than half.

In another study, baculovirus from cell culture supernatant was successfully purified using the anion exchange monolithic column $\mathrm{CIM}^{\circledR}$ QA [30]. The authors were able to reduce the volume 82-fold, increase activity 51-fold and remove $99 \%$ of the contaminants. More successful applications of monolithic columns for the purification of viruses are summarized in Table 1. 


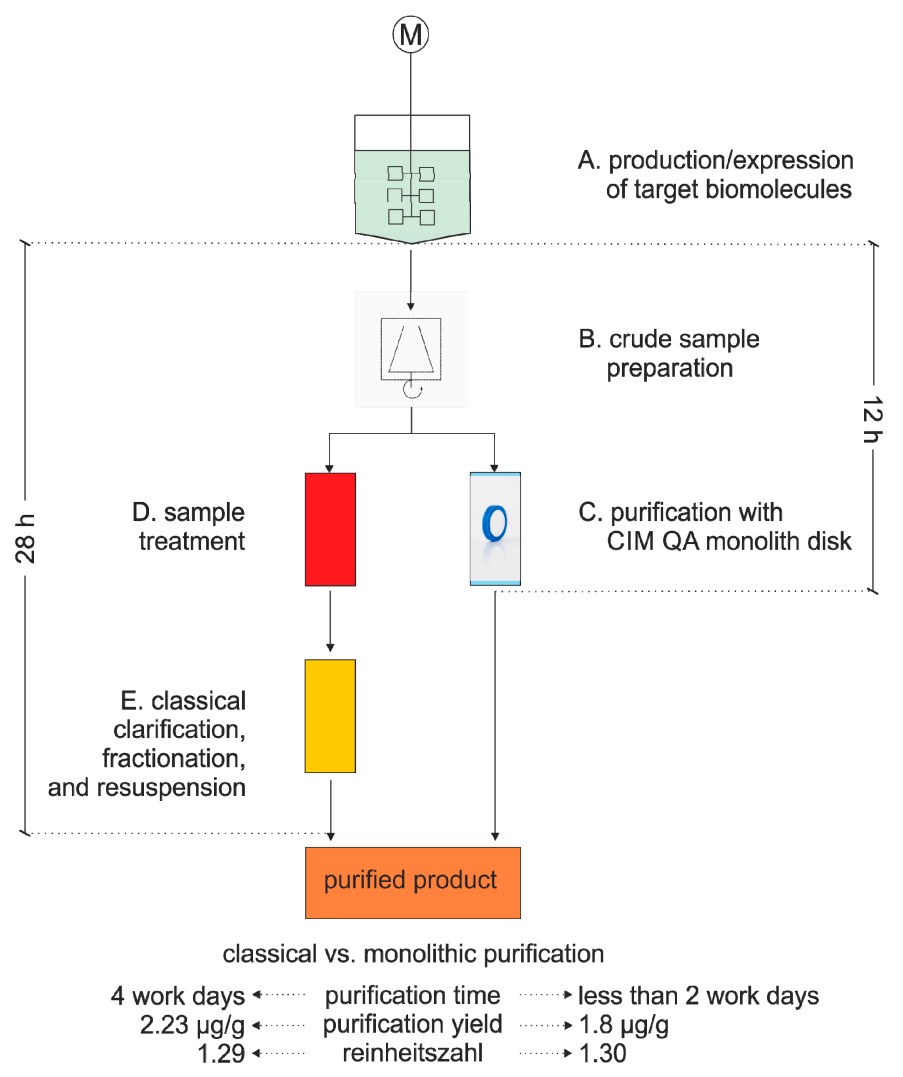

Figure 2. Schematic comparison of potato virus Y (PVY) purification between classical methods (A, B, D, E) and monolithic columns (A, B, C) [31].

Table 1. Applications of monolithic columns for purification and concentration of viruses.

\begin{tabular}{|c|c|c|c|}
\hline Virus & Host & Monolith & Ref. \\
\hline Bacteriophage T4 & E. coli & \multirow[b]{2}{*}{$\mathrm{CIM}^{\circledR} \mathrm{QA}$} & [43] \\
\hline Flavivirus particles & $\begin{array}{l}\text { Vero and baby hamster } \\
\text { kidney (BHK) helper cells }\end{array}$ & & [44] \\
\hline $\begin{array}{l}\text { Adenovirus type } 3 \text { dodecahedric } \\
\text { virus-like particles (VLP) }\end{array}$ & High-Five cells & $\begin{array}{l}\mathrm{CIM}^{\circledR} \text { analytical column } \\
\left(\mathrm{CIMac}^{\circledR}\right) \text { QA }\end{array}$ & [45] \\
\hline Bacteriophage T7 & E. coli & 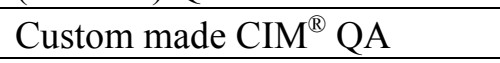 & [46] \\
\hline Mycobacteriophage D29 & M. smegmatis & \multirow{3}{*}{ CIM $^{\circledR}$ DEAE (diethylamine) } & [47] \\
\hline Enterovirus 71 & Rhabdomyosarcoma cells & & [48] \\
\hline Lentiviral vectors & HEK 293T cells & & [49] \\
\hline & $293 \mathrm{~T} / 17$ cells & $\begin{array}{l}\mathrm{CIM}^{\circledR}-\mathrm{IDA}(\text { iminodiacetic acid }) \\
-\mathrm{Ni}^{2+}\end{array}$ & {$[50]$} \\
\hline Bacteriophage VDX-10 & S. aureus & \multirow{3}{*}{$\mathrm{CIM}^{\circledR} \mathrm{QA}$ and $\mathrm{CIM}^{\circledR}$ DEAE } & [51] \\
\hline Bacteriophage PRD 1 & E.coli and $S$. enterica & & [52] \\
\hline Burkholderia phage Phi208 & B. thailandensis & & [53] \\
\hline Rubella virus & $\begin{array}{l}\text { Human fetal lung fibroblast } \\
\text { (MRC-5) cells }\end{array}$ & $\mathrm{CIM}^{\circledR} \mathrm{QA}$ and $\mathrm{CIM}^{\circledR} \mathrm{SO} 3$ & [54] \\
\hline Influenza virus $\mathrm{A}$ and $\mathrm{B}$ & Vero cells & $\begin{array}{l}\mathrm{CIM}^{\circledR} \mathrm{QA}, \mathrm{CIM}^{\circledR} \text { DEAE and } \\
\mathrm{CIM}^{\circledR} \mathrm{SO} 3\end{array}$ & [55] \\
\hline VLPs (HBsAg) & S. cerevisiae & $\mathrm{CIM}^{\circledR} \mathrm{C} 4$ and $\mathrm{CIM}^{\circledR} \mathrm{OH}$ & [29] \\
\hline Bacteriophage Phi6 & P. syringae & $\mathrm{CIM}^{\mathbb{R}} \mathrm{QA}$ & [56] \\
\hline Potato virus $\mathrm{Y}$ & $\begin{array}{l}\text { Plant tissue; N. tabacum } \\
\text { and S. tuberosum }\end{array}$ & $\mathrm{CIM}^{\circledR} \mathrm{QA}$ & [31] \\
\hline
\end{tabular}




\subsection{Nucleic Acid Purification}

Since the introduction of plasmid-based DNA (pDNA) therapeutics in the 1990s [57], they have been extensively used in medical diagnostics. In 2003, the first DNA vaccine for human therapy was approved [58]. These therapeutic applications require high amounts of highly pure pDNA. There is a variety of purification strategies available for the purification of pDNA using conventional methods, including tangential flow filtration (TFF) [59-61], membrane adsorption [62-64] and chromatography $[65,66]$. Monolithic columns with different functionalities have also been tested for the purification of pDNA. In the past few years, several studies described the successful grafting of a weak anion exchange monolithic column $\left(\mathrm{CIM}^{\circledR}\right.$ DEAE) with different functionalities, such as hydrophobic and ion exchange moieties, to allow pDNA purification in only a single step [67-69]. This concept, called conjoint liquid chromatography (CLC), allows the formation of mixed mode monoliths. This provides a much faster, but still a very efficient alternative to the conventional multi-step procedure (Figure 3). The one-step strategy proved efficient for removal of over 99\% of gDNA, RNA and host cell proteins and was able to achieve highly pure pDNA from cell culture. Theoretically, this strategy can easily be scaled up, giving a total amount of $15 \mathrm{~g}$ of pDNA, which can be purified with an 8-L column in only one single loading step [67]. However, monolithic columns have not only been employed for the purification of pDNA, but also for other nucleic acids (Table 2).

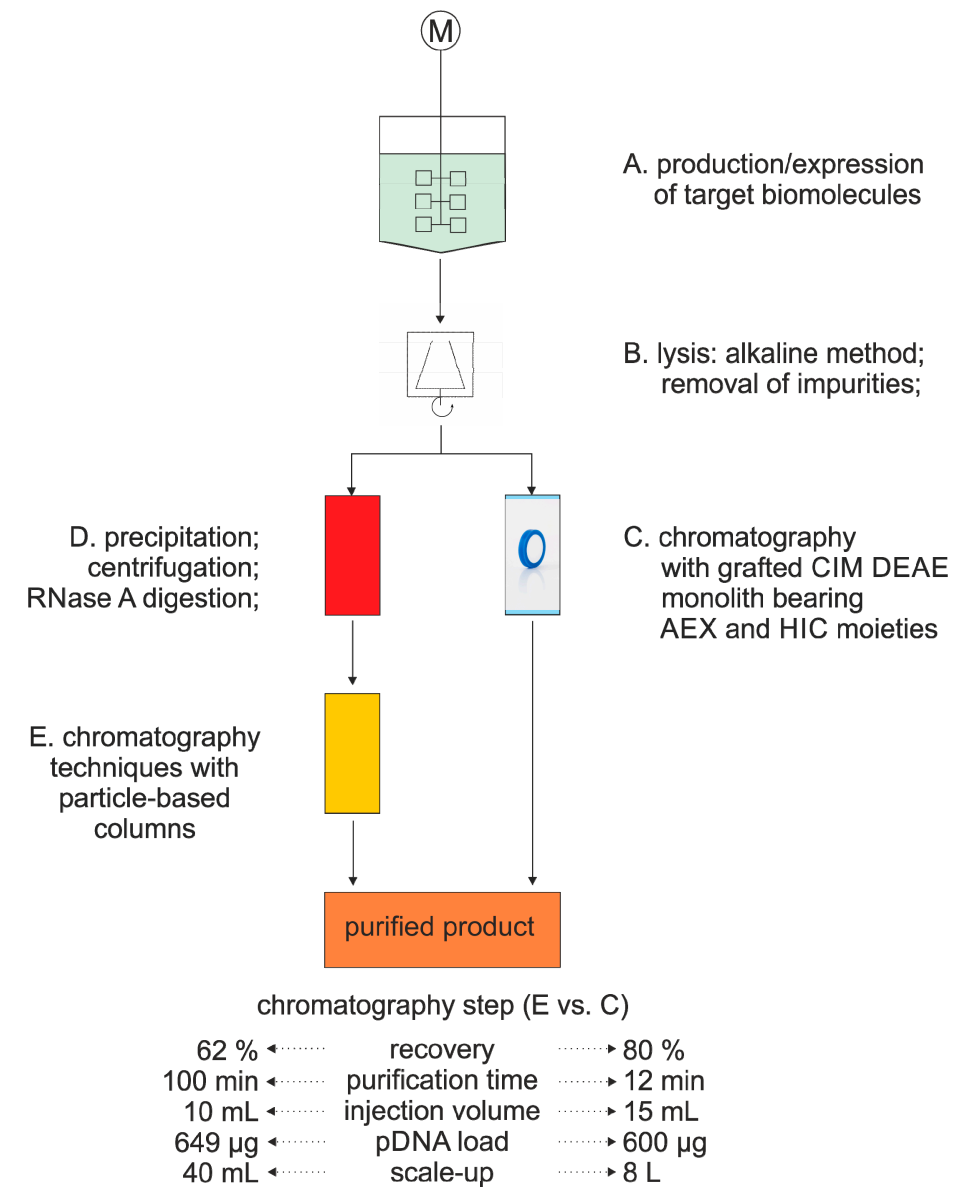

Figure 3. Schematic comparison of pDNA purification between conventional methods (A, B, D, E) [65] and monolithic columns (A, B, C) [67]. AEX, anion exchange chromatography; HIC, hydrophobic interaction chromatography. 
Table 2. Applications of monolithic columns for the purification of nucleic acids.

\begin{tabular}{|c|c|c|c|}
\hline Nucleic acid & Host & Monolith & Ref. \\
\hline Plasmids & E. coli & CIM $^{\circledR}$ DEAE & {$[70]$} \\
\hline pDNA & E. coli & CIM $^{\circledR}$ DEAE bearing HIC and AEX groups & [67] \\
\hline pDNA & E. coli & $\begin{array}{l}\mathrm{CIM}^{\circledR} \text { DEAE, } \mathrm{CIM}^{\circledR} \mathrm{QA} \text { and } \mathrm{CIM}^{\circledR} \mathrm{C} 4 \mathrm{HLD} \text { (high } \\
\text { ligand density) }\end{array}$ & {$[69]$} \\
\hline pDNA HPV-16 E6/E7 & E. coli & $\begin{array}{l}\text { CIMac }^{\circledR} \text { pDNA and } \\
\text { Custom made CIM }{ }^{\circledR} \text {-CDI (carboxydiimidazole) - } \\
\text { arginine }\end{array}$ & {$[71,72]$} \\
\hline scpDNA & E. coli & $\begin{array}{l}\text { Custom made } \\
\text { CIM }^{\circledR} \text {-CDI-histamine amino acid derivative }\end{array}$ & {$[73]$} \\
\hline ocpDNA & E. coli & $\mathrm{CIMac}^{\circledR} \mathrm{pDNA}$ & {$[74]$} \\
\hline pDNA & DH5- $\alpha$ mutants & $\mathrm{CIM}^{\circledR}-\mathrm{CDI}-\mathrm{Cu}^{2+}$ & {$[75]$} \\
\hline $\begin{array}{l}\text { pCCIFOS-25 } \\
\text { (ds circular DNA) }\end{array}$ & E.coli & $\begin{array}{l}\text { Laboratory made } \\
\text { poly (glycidyl methacrylate - ethylene glycol } \\
\text { dimethacrylate) column }\end{array}$ & {$[76]$} \\
\hline pre-miR-29 & R. sulfidophilum & $\begin{array}{l}\text { Custom made } \\
\text { CIM }^{\circledR} \text {-CDI-agmatine }\end{array}$ & {$[77]$} \\
\hline
\end{tabular}

\subsection{Protein Purification}

In conventional particle-based chromatography, different protein properties, like the isoelectric point and hydrophobicity, can be used to purify the product. Typical purification strategies comprise ion-exchange (IEX) and hydrophobic interaction (HIC) approaches, as well as the use of affinity tags. Since different raw materials and, thus, chemistries can be used for monoliths, the same purification principles can be applied there (Table 3). To mention only a few examples, ion-exchange monoliths have been successfully used for the purification of coagulation factors and recombinant proteins [78,79]; myoglobin, lysozyme [80] and bovine serum albumin [81] were purified by HIC monoliths; and affinity chromatography was employed for the purification of immunoglobulin $\mathrm{G}$ using a CIM $^{\circledR}$ r-Protein A monolithic column [82,83]. More applications of monoliths for the purification of proteins are shown in Table 3.

Table 3. Applications of monolithic columns for the purification of proteins.

\begin{tabular}{|c|c|c|c|}
\hline Protein & Host & Monolith & Ref. \\
\hline TNF- $\alpha$ & E. coli & $\mathrm{CIM}^{\circledR}$ DEAE and $\mathrm{CIM}^{\circledR}$-IDA-Cu ${ }^{2+}$ & [84] \\
\hline $\begin{array}{l}\text { Horseradish } \\
\text { peroxidase }\end{array}$ & P. pastoris & $\mathrm{CIM}^{\circledR}$ DEAE & [79] \\
\hline$\beta$-glucosidases & P. etchellsii & CIM $^{\circledR}$ DEAE and CIM $^{\circledR}$ EDA (ethylendiamino) & [85] \\
\hline Host cell proteins & CHO cells & CIM $^{\circledR}$ Protein-A HLD & [86] \\
\hline IgM & IgM clone 84 & $\mathrm{CIM}^{\circledR} \mathrm{SO}_{3}, \mathrm{CIM}^{\circledR}$ DEAE and $\mathrm{CIM}^{\circledR} \mathrm{CDI}$ & [87] \\
\hline $\begin{array}{l}\text { proteins extracted } \\
\text { from blood group } \\
\text { antigens }\end{array}$ & $\begin{array}{l}\text { anti-V5 hybridoma } \\
\text { cell line }\end{array}$ & Custom made $\mathrm{CIM}^{\circledR}$ epoxy & [88] \\
\hline IgG1 & Hybridoma cells & $\begin{array}{l}\mathrm{CIM}^{\circledR} \text {-IDA with four different metal ions, namely } \\
\mathrm{Cu}^{2+}, \mathrm{Ni}^{2+}, \mathrm{Zn}^{2+}, \mathrm{Co}^{2+}\end{array}$ & [89] \\
\hline Factor IX & $\mathrm{CHO}$ cells & $\mathrm{CIM}^{\circledR} \mathrm{QA}$ & {$[78]$} \\
\hline
\end{tabular}


A prominent example for the use of a monolith for protein purification is the downstream process for Factor IX (FIX), which plays an important role in blood coagulation. Ribeiro et al. tested different particle-based and monolithic anion exchange resins for the purification of recombinant FIX (rFIX) from cell culture supernatant (Figure 4; [78]). Four different supports, namely monolith $\mathrm{CIM}^{\circledR}$ QA, Sartobind $^{\circledR}$ Q, Q Sepharose ${ }^{\circledR}$ and Fractogel ${ }^{\circledR}$ TMAE (trimethylamino ethyl), were used for screening, and a pseudo-affinity elution with calcium chloride was developed. CIM $^{\circledR}$ QA rendered the highest dynamic binding capacity in comparison to the other resins, namely $4.6 \mathrm{mg} / \mathrm{mL}$ of monolithic support. The authors conducted a design of experiments to optimize elution conditions and finally obtained a recovery yield of $83 \%$, a purification factor of 304, 99.99\% removal of DNA and 1,256-fold removal of host cell proteins in only one purification step. Upon up-scaling from a 1-mL to an 8-mL $\mathrm{CIM}^{\circledR}$ QA monolithic tube column, similar results were obtained [78].

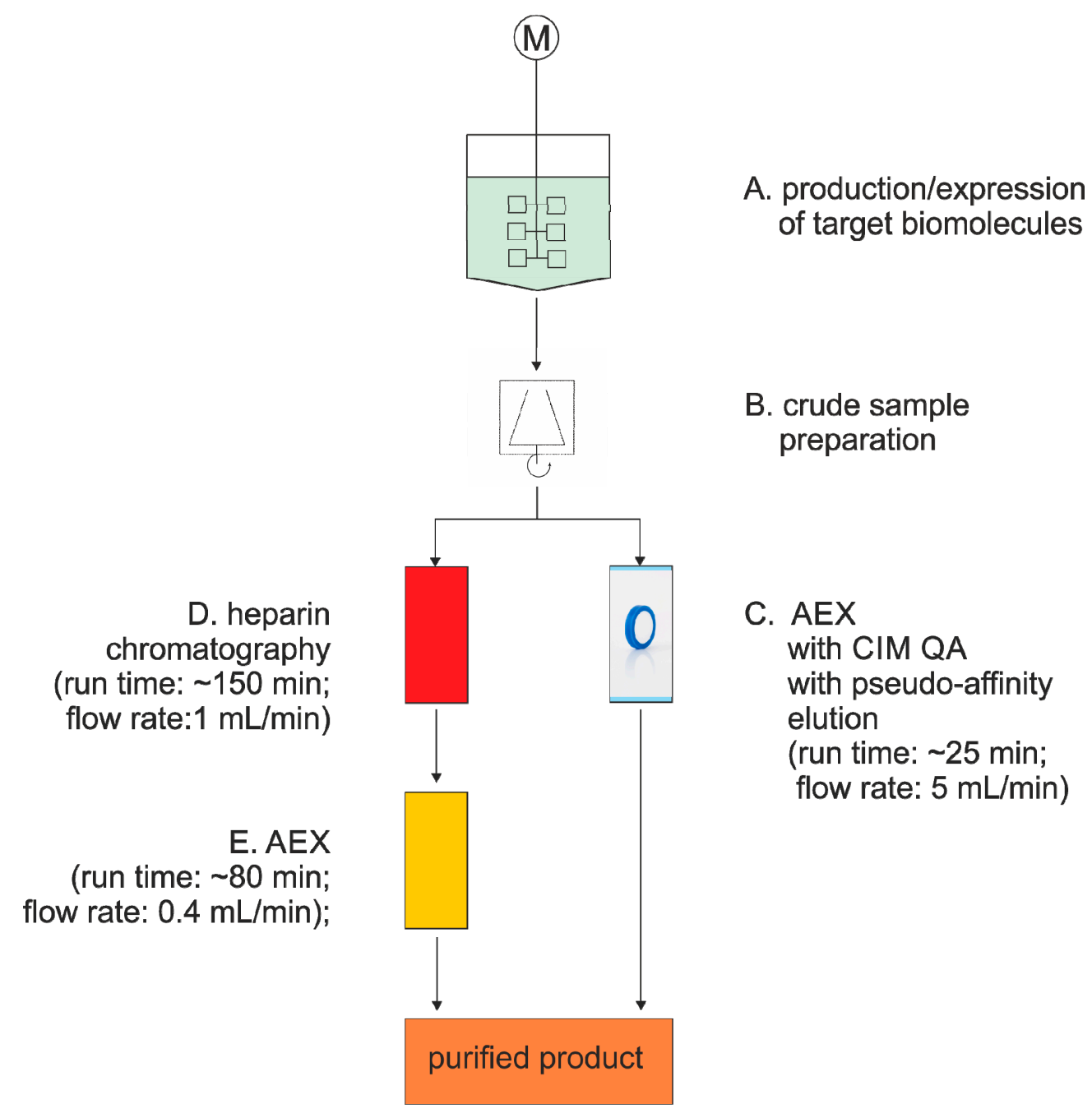

Figure 4. Schematic comparison of Factor IX (FIX) purification between conventional methods (A, B, D, E) [90] and monolithic columns (A, B, C) [78].

\section{Commercially Available Monoliths}

As shown above, monoliths are a powerful alternative to particle-based resins for the purification of biomolecules, and the first industrial processes employing monoliths have been launched. Thus, 
several providers offer monoliths of different chemistries, shapes and sizes. Polymethacrylate-based monolithic columns are currently produced and distributed by BIA separations (Ljubljana, Slovenia) under the trade name $\mathrm{CIM}^{\circledR}$ (convective interaction media), CIMac ${ }^{\circledR}$ (CIM analytical columns) and CIMmultus $^{\circledR}$. They also offer custom-made columns with different column chemistry to suit the needs of the end user. Dionex (CA, USA) also produces polymethacrylate monolithic columns under the trade name ProSwift ${ }^{\circledR}$. Phenomenex (CA, USA) markets silica-based monolithic columns under the trade name Onyx ${ }^{\circledR}$. Agilent technologies (CA, USA) markets poly-(glycidyl methacrylate-co ethylene dimethacrylate) monoliths, made by BIA separations, under the trade name Bio-monolith ${ }^{\circledR}$ [91]. Merck Millipore (MA, USA) has the trade name Chromolith ${ }^{\circledR}$ for marketing their silica-based monolithic columns. Bio-Rad (CA, USA) produces polymer-based monolithic columns under the trade name $\mathrm{Uno}^{\circledR}$. A summary of commercially available monoliths, their underlying purification principle and respective distributors is given in Table 4 .

Table 4. Commercially available monolithic columns. Chromatography techniques: CEX, cation exchange; IEX, ion exchange; HILIC, hydrophilic interaction.

\begin{tabular}{|c|c|c|c|}
\hline Monolith & Principle & Manufacturer/Supplier & Ref. \\
\hline $\mathrm{CIM}^{\circledR}, \mathrm{CIMmultus}^{\circledR}$ and $\mathrm{CIMac}^{\circledR} \mathrm{QA}$ & \multirow{5}{*}{ AEX } & \multirow{15}{*}{ BIA separations } & \multirow{15}{*}{ [19] } \\
\hline $\mathrm{CIM}^{\circledR}$, CIMmultus $^{\circledR}$ and CIMac ${ }^{\circledR}$ DEAE & & & \\
\hline $\mathrm{CIMac}^{\circledR}$ pDNA & & & \\
\hline CIMac $^{\circledR}$ Adeno & & & \\
\hline $\mathrm{CIM}^{\circledR}$ and $\mathrm{CIMac}^{\circledR}$ EDA & & & \\
\hline $\mathrm{CIM}^{\circledR}, \mathrm{CIMmultus}^{\circledR}$ and CIMac ${ }^{\circledR} \mathrm{SO}_{3}$ & CEX & & \\
\hline $\mathrm{CIM}^{\circledR}$ and CIMmultus ${ }^{\circledR} \mathrm{C} 4 \mathrm{~A}$ & $\mathrm{HIC}$ & & \\
\hline $\mathrm{CIM}^{\circledR}$ and CIMmultus ${ }^{\circledR} \mathrm{OH}$ & HILIC & & \\
\hline $\mathrm{CIM}^{\circledR} \mathrm{CDI}$ & \multirow{7}{*}{ Affinity } & & \\
\hline $\mathrm{CIM}^{\circledR}$ IDA & & & \\
\hline CIM $^{\circledR}$ n-Protein A & & & \\
\hline $\mathrm{CIM}^{\circledR}$ r-Protein A & & & \\
\hline $\mathrm{CIM}^{\circledR}$ r-Protein $\mathrm{G}$ & & & \\
\hline $\mathrm{CIM}^{\circledR}$ r-Protein L & & & \\
\hline $\mathrm{CIM}^{\circledR}$ epoxy & & & \\
\hline ProSwift ${ }^{\mathbb{R}}$ RP monolith column & $\mathrm{HIC}$ & \multirow{5}{*}{ Dionex } & \multirow{5}{*}{ [92] } \\
\hline ProSwift $^{\mathbb{B}}$ IEX monolith column & IEX & & \\
\hline ProSwift $^{\mathbb{B}}$ ConA-1S affinity monolith column & Affinity & & \\
\hline DNASwift ${ }^{\circledR}$ SAX-1S monolith column & \multirow{2}{*}{ AEX } & & \\
\hline PepSwift ${ }^{\mathbb{B}}$ monolith column & & & \\
\hline Onyx ${ }^{\circledR}$ monolithic $\mathrm{C} 18$ column & \multirow{5}{*}{$\mathrm{HIC}$} & \multirow{5}{*}{ Phenomenex } & \multirow{5}{*}{ [93] } \\
\hline Onyx ${ }^{\circledR}$ monolithic $\mathrm{C} 8$ column & & & \\
\hline Onyx ${ }^{\circledR}$ monolithic HD-C18 & & & \\
\hline Onyx ${ }^{\circledR}$ monolithic Si & & & \\
\hline Chromolith $^{\circledR}$ RP-18e & & & \\
\hline Bio-Monolith ${ }^{\circledR} \mathrm{QA}$ & \multirow{2}{*}{ AEX } & \multirow{4}{*}{ Agilent technologies } & \multirow{4}{*}{ [94] } \\
\hline Bio-Monolith ${ }^{\circledR}$ DEAE & & & \\
\hline Bio-Monolith ${ }^{\circledR} \mathrm{SO}_{3}$ & CEX & & \\
\hline Bio-Monolith ${ }^{\circledR}$ Protein A & Affinity & & \\
\hline
\end{tabular}


Table 4. Cont.

\begin{tabular}{|c|c|c|c|}
\hline Monolith & Principle & Manufacturer/Supplier & Ref. \\
\hline $\begin{array}{l}\text { Chromolith }{ }^{\circledR} \text { CapRod RP-18 endcapped 300-0.1 capillary } \\
\text { column }\end{array}$ & \multirow{7}{*}{$\mathrm{HIC}$} & \multirow{7}{*}{ Merck Millipore } & \multirow{7}{*}{ [95] } \\
\hline Chromolith ${ }^{\circledR}$ Phenyl 50-4.6 HPLC column & & & \\
\hline $\begin{array}{l}\text { Chromolith }{ }^{\circledR} \text { FastGradient RP-18 endcapped 50-2 HPLC } \\
\text { column }\end{array}$ & & & \\
\hline $\begin{array}{l}\text { Chromolith }{ }^{\circledR} \text { FastGradient RP-18 endcapped 100-3 HPLC } \\
\text { column }\end{array}$ & & & \\
\hline Chromolith ${ }^{\circledR}$ Flash RP-18 endcapped 25-2 HPLC column & & & \\
\hline Chromolith ${ }^{\circledR}$ Flash RP-18 endcapped 25-3 HPLC column & & & \\
\hline Chromolith ${ }^{\circledR}$ Prep RP-18 endcapped 100-25 column & & & \\
\hline $\mathrm{UNO}^{\circledR}$ Monolith Anion Exchange Columns & AEX & \multirow{8}{*}{ Bio-Rad } & \multirow{8}{*}{ [96] } \\
\hline UNO $^{\circledR}$ Monolith Cation Exchange Columns & CEX & & \\
\hline $\mathrm{UNO}^{\circledR} \mathrm{S} 1$ Column & \multirow{6}{*}{ IEX } & & \\
\hline $\mathrm{UNO}^{\circledR}$ S6 Column & & & \\
\hline $\mathrm{UNO}^{\circledR} \mathrm{S} 12$ Column & & & \\
\hline $\mathrm{UNO}^{\circledR} \mathrm{Q} 1$ Column & & & \\
\hline $\mathrm{UNO}^{\circledR}$ Q6 Column & & & \\
\hline $\mathrm{UNO}^{\circledR} \mathrm{Q} 12$ Column & & & \\
\hline
\end{tabular}

\section{Concluding Remarks and Outlook}

In terms of resolution and separation speed, monolithic columns outperform particle-based resins. Furthermore, scale-up does not affect the resolution of monolithic purification processes. It was shown that the dynamic binding capacity of monoliths, which is comparable to particle-based resins, actually increases with increasing product size. Furthermore, the possibility of using different raw materials, chemistries, pore sizes and grafting, which allows a high degree of freedom for the operator, causes an overwhelming interest in monoliths today. Our research group is currently conducting experiments to implement monolith technology as an impurity monitoring process analytical technology (PAT) tool across unit operations. In a similar approach, Smrekar et al. already implemented the monolith technology as a PAT tool to monitor a virus production process [97].

Another highly interesting approach was recently given by Fee et al., who used a 3D printer to manufacture monoliths with hexagonal channels from computer-aided design (CAD) models [98]. This allows more control in pore formation and distribution and might further boost the performance and applicability of monolith technology in the future.

\section{Acknowledgments}

The authors are grateful to BIA separations for providing monolithic columns and technical support. 


\section{Author Contributions}

Vignesh Rajamanickam processed the literature and extracted relevant information. Vignesh Rajamanickam and Oliver Spadiut wrote the manuscript. Christoph Herwig and Oliver Spadiut supervised the work.

\section{Conflicts of Interest}

The authors declare no conflict of interest.

\section{References}

1. Center for Chemical Process Safety (CCPS). Guidelines for Process Safety in Bioprocess Manufacturing Facilities; Wiley: Hoboken, NJ, USA, 2010; p. 225.

2. Kling, J. The Downstream Pinch-Upstream efficiencies, economic forces and changing technologies complicate separation and purification. BioProcess Int. 2014, 12, 1-9.

3. Jungbauer, A.; Hahn, R. Polymethacrylate monoliths for preparative and industrial separation of biomolecular assemblies. J. Chromatogr. A 2008, 1184, 62-79.

4. Podgornik, A.; Savnik, A.; Jančar, J.; Krajnc, N.L. Design of monoliths through their mechanical properties. J. Chromatogr. A 2014, 1333, 9-17.

5. Podgornik, A.; Smrekar, V.; Krajnc, P.; Strancar, A. Estimation of methacrylate monolith binding capacity from pressure drop data. J. Chromatogr. A 2013, 1272, 50-55.

6. Stulík, K.; Pacáková, V.; Suchánková, J.; Coufal, P. Monolithic organic polymeric columns for capillary liquid chromatography and electrochromatography. J. Chromatogr. B. 2006, 841, 79-87.

7. Tennikova, T.B.; Bleha, M.; Švec, F. High-performance membrane chromatography of proteins, a novel method of protein separation. J. Chromatogr. A 2001, 555, 97-107.

8. Tennikova, T.B.; Svec, F.; Belenkii, B.G. High-Performance Membrane Chromatography. A Novel Method of Protein Separation. J. Liq. Chromatogr. 1990, 13, 63-70.

9. Belenkii, B.G.; Podkladenko, A.M. Peculiarities of zone migration and band broadening in gradient reversed-phase high-performance liquid chromatography of proteins with respect to membrane chromatography. J. Chromatogr. A 2001, 645, 1-15.

10. Svec, F.; Tennikova, T.B.; Deyl, Z. Monolithic Materials: Preparation, Properties and Applications; Elsevier B. V.: Amsterdam, The Netherlands, 2003; Volume 67, pp. 1-773.

11. Hilder, E.F.; Svec, F.; Fréchet, J.M. Development and application of polymeric monolithic stationary phases for capillary electrochromatography. J. Chromatogr. A 2004, 1044, 3-22.

12. Svec, F. Recent developments in the field of monolithic stationary phases for capillary electrochromatography. J. Sep. Sci. 2005, 28, 729-745.

13. Dubinina, N.I.; Kurenbin, O.I.; Tennikova, T.B. Peculiarities of gradient ion-exchange highperformance liquid chromatography of proteins. J. Chromatogr. A 1996, 753, 217-225.

14. Guiochon, G. Monolithic columns in high-performance liquid chromatography. J. Chromatogr. A 2007, 1168, 101-168; discussion 100.

15. Siouffi, A.-M. Monolithic columns in high-performance liquid chromatography. J. Chromatogr. A 2006, 1126, 86-94. 
16. Vlakh, E.G.; Tennikova, T.B. Applications of polymethacrylate-based monoliths in highperformance liquid chromatography. J. Chromatogr. A 2009, 1216, 2637-2650.

17. Jandera, P. Advances in the development of organic polymer monolithic columns and their applications in food analysis-A review. J. Chromatogr. A 2013, 1313, 37-53.

18. Pfaunmiller, E.L.; Paulemond, M.L.; Dupper, C.M.; Hage, D.S. Affinity monolith chromatography: A review of principles and recent analytical applications. Anal. Bioanal. Chem. 2013, 405, 2133-2145.

19. BIAseparations Bia Separations. Available online: http://www.biaseparations.com/default.asp (accessed on 6 December 2014).

20. Sheehan, D. Physical Biochemistry: Principles and Applications, 2nd ed.; Wiley: Oxford, UK, 2009; p. 424.

21. Strancar, A.; Podgornik, A.; Barut, M.; Necina, R. Short Monolithic Columns as Stationary Phases for Biochromatography. In Modern Advances in Chromatography; Springer-Verlag: Berlin Heidelberg, Germany, 2002; pp. 49-85.

22. Vlakh, E.G.; Tennikova, T.B. Preparation of methacrylate monoliths. J. Sep. Sci. 2007, 30, 2801-2813.

23. Svec, F.; Frechet, J.M.J. Kinetic Control of Pore Formation in Macroporous Polymers. Formation of "Molded" Porous Materials with High Flow Characteristics for Separations or Catalysis. Chem. Mater. 1995, 7, 707-715.

24. Svec, F.; Frechet, J.M.J. Temperature, a simple and efficient tool for the control of pore size distribution in macroporous polymers. Macromolecules 1995, 28, 7580-7582.

25. Merhar, M.; Podgornik, A.; Barut, M.; Žigon, M.; Štrancar, A. Methacrylate monoliths prepared from various hydrophobic and hydrophilic monomers-Structural and chromatographic characteristics. J. Sep. Sci. 2003, 26, 322-330.

26. Barut, M.; Podgornik, A.; Urbas, L.; Gabor, B.; Brne, P.; Vidic, J.; Plevcak, S.; Strancar, A. Methacrylate-based short monolithic columns: Enabling tools for rapid and efficient analyses of biomolecules and nanoparticles. J. Sep. Sci. 2008, 31, 1867-1880.

27. Benčina, M.; Podgornik, A.; Štrancar, A. Characterization of methacrylate monoliths for purification of DNA molecules. J. Sep. Sci. 2004, 27, 801-810.

28. Krajnc, N.L.; Smrekar, F.; Cerne, J.; Raspor, P.; Modic, M.; Krgovic, D.; Strancar, A.; Podgornik, A. Purification of large plasmids with methacrylate monolithic columns. J. Sep. Sci. 2009, 32, 2682-2690.

29. Burden, C.S.; Jin, J.; Podgornik, A.; Bracewell, D.G. A monolith purification process for virus-like particles from yeast homogenate. J. Chromatogr. B. 2012, 880, 82-89.

30. Gerster, P.; Kopecky, E.-M.; Hammerschmidt, N.; Klausberger, M.; Krammer, F.; Grabherr, R.; Mersich, C.; Urbas, L.; Kramberger, P.; Paril, T.; et al. Purification of infective baculoviruses by monoliths. J. Chromatogr. A 2013, 1290, 36-45.

31. Rupar, M.; Ravnikar, M.; Tušek-Žnidarič, M.; Kramberger, P.; Glais, L.; Gutiérrez-Aguirre, I. Fast purification of the filamentous Potato virus $\mathrm{Y}$ using monolithic chromatographic supports. J. Chromatogr. A 2013, 1272, 33-40. 
32. El Deeb, S.; Wätzig, H. Performance comparison between monolithic C18 and conventional C18 particle-packed columns in the liquid chromatographic determination of propranolol $\mathrm{HCl}$. Turkish J. Chem. 2006, 30, 543-552.

33. Szumski, M.; Buszewski, B. Preparation of Monolithic Capillary Chromatographic Columns Using Supercritical Fluid as a Porogen Solvent. Chromatographia 2014, 77, 1009-1017.

34. Ou, J.; Liu, Z.; Wang, H.; Lin, H.; Dong, J.; Zou, H. Recent development of hybrid organic-silica monolithic columns in CEC and capillary LC. Electrophoresis 2015, 36, 62-75.

35. Chen, M.-L.; Zheng, M.-M.; Feng, Y.-Q. Preparation of organic-inorganic hybrid silica monolith with octyl and sulfonic acid groups for capillary electrochromatograhpy and application in determination of theophylline and caffeine in beverage. J. Chromatogr. A 2010, 1217, 3547-3556.

36. Mayadunne, E.; El Rassi, Z. Facile preparation of octadecyl monoliths with incorporated carbon nanotubes and neutral monoliths with coated carbon nanotubes stationary phases for HPLC of small and large molecules by hydrophobic and $\pi-\pi$ interactions. Talanta 2014, 129, 565-574.

37. Peyrin, E.; Caron, C.; Garrel, C.; Ravel, A.; Villet, A.; Grosset, C.; Favier, A. DNA migration regimes in hydrodynamic chromatography and slalom chromatography: Evidence for a transition. 2001, 55, 291-296.

38. Perrin, F.X.; Courderot, C.; Truong, T.; Pierre, J.; Thomassin, M.; Guinchard, C.; Guillaume, Y.C.; Nicod, L. Supercoiled circular DNA and protein retention in non-equilibrium chromatography Temperature and velocity dependence: Testimony of a transition. J. Chromatogr. A 2002, 950, 281-285.

39. Urban, J.; Jandera, P.; Schoenmakers, P. Preparation of monolithic columns with target mesoporesize distribution for potential use in size-exclusion chromatography. J. Chromatogr. A 2007, 1150, 279-289.

40. Hu, Y.-C. Baculovirus Vectors for Gene Therapy. Adv. Virus Res. 2006, 68, 287-320.

41. Wang, C.-Y.; Li, F.; Yang, Y.; Guo, H.-Y.; Wu, C.-X.; Wang, S. Recombinant baculovirus containing the diphtheria toxin A gene for malignant glioma therapy. Cancer Res. 2006, 66, 57985806.

42. Chen, G.-Y.; Chen, C.-Y.; Chang, M.D.-T.; Matsuura, Y.; Hu, Y.-C. Concanavalin A affinity chromatography for efficient baculovirus purification. Biotechnol. Prog. 2009, 25, 1669-1677.

43. Smrekar, F.; Ciringer, M.; Peterka, M.; Podgornik, A. Strancar, a Purification and concentration of bacteriophage T4 using monolithic chromatographic supports. J. Chromatogr. B 2008, 861, 177-180.

44. Mundle, S.T.; Giel-Moloney, M.; Kleanthous, H.; Pugachev, K.V.; Anderson, S.F. Preparation of pure, high titer, pseudoinfectious Flavivirus particles by hollow fiber tangential flow filtration and anion exchange chromatography. Vaccine 2014, in press.

45. Urbas, L.; Jarc, B.L.; Barut, M.; Zochowska, M.; Chroboczek, J.; Pihlar, B.; Szolajska, E. Purification of recombinant adenovirus type 3 dodecahedric virus-like particles for biomedical applications using short monolithic columns. J. Chromatogr. A 2011, 1218, 2451-2459.

46. Smrekar, F.; Ciringer, M.; Strancar, A.; Podgornik, A. Characterisation of methacrylate monoliths for bacteriophage purification. J. Chromatogr. A 2011, 1218, 2438-2444. 
47. Liu, K.; Wen, Z.; Li, N.; Yang, W.; Hu, L.; Wang, J.; Yin, Z.; Dong, X.; Li, J. Purification and concentration of mycobacteriophage D29 using monolithic chromatographic columns. J. Virol. Methods 2012, 186, 7-13.

48. Kattur Venkatachalam, A.R.; Szyporta, M.; Kiener, T.K.; Balraj, P.; Kwang, J. Concentration and purification of enterovirus 71 using a weak anion-exchange monolithic column. Virol. J. 2014, 11, 99.

49. Bandeira, V.; Peixoto, C.; Rodrigues, A.F.; Cruz, P.E.; Alves, P.M.; Coroadinha, A.S.; Carrondo, M.J.T. Downstream processing of lentiviral vectors: Releasing bottlenecks. Hum. Gene Ther. Methods 2012, 23, 255-263.

50. Cheeks, M.C.; Kamal, N.; Sorrell, A.; Darling, D.; Farzaneh, F.; Slater, N.K.H. Immobilized metal affinity chromatography of histidine-tagged lentiviral vectors using monolithic adsorbents. J. Chromatogr. A 2009, 1216, 2705-2711.

51. Kramberger, P.; Honour, R.C.; Herman, R.E.; Smrekar, F.; Peterka, M. Purification of the Staphylococcus aureus bacteriophages VDX-10 on methacrylate monoliths. J. Virol. Methods 2010, 166, 60-64.

52. Oksanen, H.M.; Domanska, A.; Bamford, D.H. Monolithic ion exchange chromatographic methods for virus purification. Virology 2012, 434, 271-277.

53. Adriaenssens, E.M.; Lehman, S.M.; Vandersteegen, K.; Vandenheuvel, D.; Philippe, D.L.; Cornelissen, A.; Clokie, M.R.J.; García, A.J.; De Proft, M.; Maes, M.; et al. CIM(®) monolithic anion-exchange chromatography as a useful alternative to $\mathrm{CsCl}$ gradient purification of bacteriophage particles. Virology 2012, 434, 265-270.

54. Forcic, D.; Brgles, M.; Ivancic-Jelecki, J.; Santak, M.; Halassy, B.; Barut, M.; Jug, R.; Markušić, M.; Strancar, A. Concentration and purification of rubella virus using monolithic chromatographic support. J. Chromatogr. B 2011, 879, 981-986.

55. Banjac, M.; Roethl, E.; Gelhart, F.; Kramberger, P.; Jarc, B.L.; Jarc, M.; Strancar, A.; Muster, T.; Peterka, M. Purification of Vero cell derived live replication deficient influenza A and B virus by ion exchange monolith chromatography. Vaccine 2014, 32, 2487-2492.

56. Romanovskaya, A.; Sarin, L.P.; Bamford, D.H.; Poranen, M.M. High-throughput purification of double-stranded RNA molecules using convective interaction media monolithic anion exchange columns. J. Chromatogr. A 2013, 1278, 54-60.

57. Wolff, J.A.; Malone, R.W.; Williams, P.; Chong, W.; Acsadi, G.; Jani, A.; Felgener, P.L. Direct gene transfer into mouse muscle in vivo. Science 1990, 247, 1465-1468.

58. Patil, S.D.; Rhodes, D.G.; Burgess, D.J. DNA-based therapeutics and DNA delivery systems: A comprehensive review. AAPS J. 2005, 7, E61-E77.

59. Guerrero-Germán, P.; Prazeres, D.M.F.; Guzmán, R.; Montesinos-Cisneros, R.M.; Tejeda-Mansir, A. Purification of plasmid DNA using tangential flow filtration and tandem anion-exchange membrane chromatography. Bioprocess Biosyst. Eng. 2009, 32, 615-623.

60. Eon-Duval, A.; MacDuff, R.H.; Fisher, C.A.; Harris, M.J.; Brook, C. Removal of RNA impurities by tangential flow filtration in an RNase-free plasmid DNA purification process. Anal. Biochem. 2003, 316, 66-73.

61. Kahn, D.W.; Butler, M.D.; Cohen, D.L.; Gordon, M.; Kahn, J.W.; Winkler, M.E. Purification of plasmid DNA by tangential flow filtration. Biotechnol. Bioeng. 2000, 69, 101-106. 
62. Zeng, X.; Ruckenstein, E. Membrane Chromatography: Preparation and Applications to Protein Separation. Biotechnol. Prog. 1999, 15, 1003-1019.

63. Kendall, D.; Lye, G.J.; Levy, M.S. Purification of plasmid DNA by an integrated operation comprising tangential flow filtration and nitrocellulose adsorption. Biotechnol. Bioeng. 2002, 79, 816-822.

64. Endres, H.N.; Johnson, J.A.; Ross, C.A.; Welp, J.K.; Etzel, M.R. Evaluation of an ion-exchange membrane for the purification of plasmid DNA. Biotechnol. Appl. Biochem. 2003, 37, 259-266.

65. Prazeres, D.M.F.; Schluep, T.; Cooney, C. Preparative purification of supercoiled plasmid DNA using anion-exchange chromatography. J. Chromatogr. A 1998, 806, 31-45.

66. Diogo, M.M.; Queiroz, J.A.; Monteiro, G.A.; Martins, S.A.; Ferreira, G.N.; Prazeres, D.M. Purification of a cystic fibrosis plasmid vector for gene therapy using hydrophobic interaction chromatography. Biotechnol. Bioeng. 2000, 68, 576-583.

67. Smrekar, V.; Smrekar, F.; Strancar, A.; Podgornik, A. Single step plasmid DNA purification using methacrylate monolith bearing combination of ion-exchange and hydrophobic groups. J. Chromatogr. A 2013, 1276, 58-64.

68. Peterka, M.; Glover, D.; Kramberger, P.; Banjac, M.; Podgornik, A.; Barut, M.; Štrancar, A. Short Monolithic Columns-An Enabling Technology for the Purification of Proteins, DNA, and Viruses. Bioprocess. J. 2005, 4, 79-84.

69. Smrekar, F.; Podgornik, A.; Ciringer, M.; Kontrec, S.; Raspor, P.; Strancar, A.; Peterka, M. Preparation of pharmaceutical-grade plasmid DNA using methacrylate monolithic columns. Vaccine 2010, 28, 2039-2045.

70. Krajnc, N.L.; Smrekar, F.; Strancar, A.; Podgornik, A. Adsorption behavior of large plasmids on the anion-exchange methacrylate monolithic columns. J. Chromatogr. A 2011, 1218, 2413-2424.

71. Almeida, A.M.; Queiroz, J.A.; Sousa, F.; Sousa, A. Optimization of supercoiled HPV-16 E6/E7 plasmid DNA purification with arginine monolith using design of experiments. J. Chromatogr. B 2014, 978-979C, 145-150.

72. Soares, A.; Queiroz, J.A.; Sousa, F.; Sousa, A. Purification of human papillomavirus 16 E6/E7 plasmid deoxyribonucleic acid-based vaccine using an arginine modified monolithic support. J. Chromatogr. A 2013, 1320, 72-79.

73. Sousa, A.; Almeida, A.M.; Černigoj, U.; Sousa, F.; Queiroz, J.A. Histamine monolith versatility to purify supercoiled plasmid deoxyribonucleic acid from Escherichia coli lysate. J. Chromatogr. A 2014, 1355, 125-133.

74. Gabor, B.; Černigoj, U.; Barut, M.; Štrancar, A. Reversible entrapment of plasmid deoxyribonucleic acid on different chromatographic supports. J. Chromatogr. A 2013, 1311, 106114.

75. Shin, M.J.; Tan, L.; Jeong, M.H.; Kim, J.-H.; Choe, W.-S. Monolith-based immobilized metal affinity chromatography increases production efficiency for plasmid DNA purification. J. Chromatogr. A 2011, 1218, 5273-5278.

76. Ongkudon, C.M.; Pan, S.; Danquah, M.K. An innovative monolithic column preparation for the isolation of 25 kilo base pairs DNA. J. Chromatogr. A 2013, 1318, 156-162.

77. Pereira, P.; Sousa, A.; Queiroz, J.A.; Figueiras, A.; Sousa, F. Pharmaceutical-grade pre-miR-29 purification using an agmatine monolithic support. J. Chromatogr. A 2014, 1368, 173-182. 
78. Ribeiro, D.A.; Passos, D.F.; Ferraz, H.C.; Castilho, L.R. Anion-exchange purification of recombinant factor IX from cell culture supernatant using different chromatography supports. J. Chromatogr. B 2013, 938, 111-118.

79. Krainer, F.W.; Pletzenauer, R.; Rossetti, L.; Herwig, C.; Glieder, A.; Spadiut, O. Purification and basic biochemical characterization of 19 recombinant plant peroxidase isoenzymes produced in Pichia pastoris. Protein Expr. Purif. 2014, 95, 104-112.

80. Hemström, P.; Nordborg, A.; Irgum, K.; Svec, F.; Fréchet, J.M.J. Polymer-based monolithic microcolumns for hydrophobic interaction chromatography of proteins. J. Sep. Sci. 2006, 29, 25-32.

81. Chen, M.-L.; Li, L.-M.; Yuan, B.-F.; Ma, Q.; Feng, Y.-Q. Preparation and characterization of methacrylate-based monolith for capillary hydrophilic interaction chromatography. J. Chromatogr. A 2012, 1230, 54-60.

82. Leblebici, P.; Leblebici, M.E.; Ferreira-da-Silva, F.; Rodrigues, A.E.; Pais, L.S. Separation of human immunoglobulin $\mathrm{G}$ subclasses on a protein A monolith column. J. Chromatogr. B 2014, 962, 89-93.

83. Nikolayenko, I.V.; Galkin, O.Y.; Grabchenko, N.I.; Spivak, M.Y. Preparation of highly purified human IgG, IgM, and IgA for immunization and immunoanalysis. Ukr. Bioorg. Acta 2005, 2, 3-11.

84. Sushma, K.; Vijayalakshmi, M.A.; Krishnan, V.; Satheeshkumar, P.K. Cloning, expression, purification and characterization of a single chain variable fragment specific to tumor necrosis factor alpha in Escherichia coli. J. Biotechnol. 2010, 156, 238-244.

85. Gaonkar, R.K.; Mishra, S.; Vijayalakshmi, M.A. Purification of B-glucosidases from Pichia etchellsii using CIM monolith columns. Appl. Biochem. Biotechnol. 2011, 164, 68-76.

86. Tscheliessnig, A.; Jungbauer, A. High-performance monolith affinity chromatography for fast quantitation of immunoglobulin G. J. Chromatogr. A 2009, 1216, 2676-2682.

87. Gan, H.T.; Lee, J.; Latiff, S.M.A.; Chuah, C.; Toh, P.; Lee, W.Y.; Gagnon, P. Characterization and removal of aggregates formed by nonspecific interaction of $\operatorname{IgM}$ monoclonal antibodies with chromatin catabolites during cell culture production. J. Chromatogr. A 2013, 1291, 33-40.

88. Mönster, A.; Hiller, O.; Grüger, D.; Blasczyk, R.; Kasper, C. Isolation and purification of blood group antigens using immuno-affinity chromatography on short monolithic columns. J. Chromatogr. A 2011, 1218, 706-710.

89. Rajak, P.; Vijayalakshmi, M.A.; Jayaprakash, N.S. Purification of monoclonal antibodies, IgG1, from cell culture supernatant by use of metal chelate convective interaction media monolithic columns. Biomed. Chromatogr. 2012, 26, 1488-1493.

90. Lindsay, M.; Gil, G.C.; Cadiz, A.; Velander, W.H.; Zhang, C.; Van Cott, K.E. Purification of recombinant DNA-derived factor IX produced in transgenic pig milk and fractionation of active and inactive subpopulations. J. Chromatogr. A 2004, 1026, 149-157.

91. Endicott, E. Agilent Technologies, BIA Separations GmbH Sign Agreement Giving Agilent Access to BIA Separations' Bio-Monolithic Technology. Available online: http://www.agilent.com/about/ newsroom/presrel/2008/29may-ca08038.html (accessed on 22 March 2015).

92 Dionex. Available online: http:/www.dionex.com/en-us/products/columns/bio/protein/proswiftiex/lp-73379.html (accessed on 15 April 2015). 
93. Onyx HPLC information. Available online: https://www.phenomenex.com/onyx (accessed on 6 December 2014).

94. Bio-Monolith - Agilent. Available online: http://www.chem.agilent.com/en-US/products-services/ Columns-Sample-Preparation/LC-LC-MS-Columns/BioHPLC/Bio-Monolith/Pages/default.aspx (accessed on 30 January 2015).

95. Chromolith HPLC columns. Available online: http:/www.merckmillipore.com/INTL/en/ analytics-sample-prep/chromatography-for-analysis/analytical-hplc/chromolith-hplc-columns/ Rk2b.qB.cMMAAAE_hPB3.Lxi,nav (accessed on 6 December 2014).

96. Chromatography Columns - UNO monolithic columns. Available online: http://www.bio-

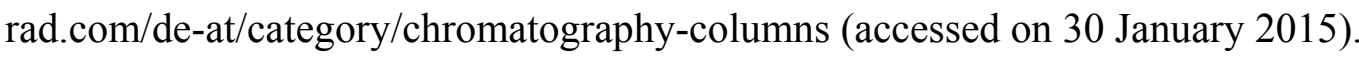

97. Smrekar, F.; Ciringer, M.; Jančar, J.; Raspor, P.; Strancar, A.; Podgornik, A. Optimization of lytic phage manufacturing in bioreactor using monolithic supports. J. Sep. Sci. 2011, 34, 2152-2158.

98. Fee, C.; Nawada, S.; Dimartino, S. 3D printed porous media columns with fine control of column packing morphology. J. Chromatogr. A 2014, 1333, 18-24.

(C) 2015 by the authors; licensee MDPI, Basel, Switzerland. This article is an open access article distributed under the terms and conditions of the Creative Commons Attribution license (http://creativecommons.org/licenses/by/4.0/). 